\title{
Dostępność Zintegrowanej Platformy Edukacyjnej dla uczniów ze specjalnymi potrzebami edukacyjnymi
}

Joanna Wojtyńska

(D) https://orcid.org/0000-0001-5559-4043

Ośrodek Rozwoju Edukacji w Warszawie 


\title{
Streszczenie
}

Spowodowane pandemią ograniczenie funkcjonowania szkół i przejście na naukę zdalną wpłynęło na zwiększenie zainteresowania stroną internetową www.epodreczniki.pl, na której znajduje się tzw. Zintegrowana Platforma Edukacyjna (ZPE). W artykule przedstawiona została geneza ZPE, jej zawartość, a przede wszystkim rozwiązanie zastosowane $\mathrm{w}$ celu zapewnienia dostosowania e-materiałów dydaktycznych, znajdujących się na powyższej stronie, do standardu WCAG oraz wymagań uczniów ze specjalnymi potrzebami edukacyjnymi (SPE). Dostosowanie materiałów zostało omówione w odniesieniu do potrzeb edukacyjnych uczniów $\mathrm{z}$ różnymi rodzajami niepełnosprawności, związanych z korzystaniem z technologii informacyjno-komunikacyjnych.

\section{Słowa kluczowe}

dostępność, edukacja online, niepełnosprawność, specjalne potrzeby edukacyjne, WCAG.

\section{Accessibility of the Integrated Educational Platform for pupils with special educational needs}

\begin{abstract}
The pandemic limitation in the functioning of schools and the transition to distance learning increased the interest in the website www.epodreczniki.pl, where is located the so-called Integrated Educational Platform (ZPE). The article presents the genesis of ZPE, its content and, above all, the solution used to ensure the adaptation of the didactic materials on the above-mentioned side to the WCAG standard and the requirements of pupils with special educational needs (SEN). The adaptation of the materials was discussed in relation to the educational needs of students with various disabilities related to the use of ICT.
\end{abstract}

\section{Keywords}

accessibility, disability, online education, special educational needs, WCAG. 
Dandemia, która ogarnęła cały świat w 2020 r., odcisnęła swoje piętno w każdej dziedzinie życia, począwszy od ochrony zdrowia, przez życie zawodowe i edukację, po nabywanie towarów i usług oraz rozrywkę. Wszędzie kontakty osobiste „twarzą w twarz” zostały ograniczone i zastąpione kontaktami telefonicznymi lub online. 11 marca $2020 \mathrm{r}$. Minister Edukacji Narodowej podjął decyzję, wynikającą z konieczności zapobiegania rozprzestrzenianiu się koronawirusa SARS-CoV-2, o czasowym ograniczeniu funkcjonowania jednostek systemu oświaty na obszarze całego kraju. W związku z tym 12 marca przedszkola, szkoły i placówki oświatowe zarówno publiczne, jak i niepubliczne, zaprzestały prowadzenia zajęć dydaktyczno-wychowawczych. Uczniowie w tym czasie mieli kontynuować kształcenie w domu, np. w formie samokształcenia lub wykorzystując materiały udostępnione przez szkoły. Zamknięcie szkół zostało ostatecznie przedłużone do 26 czerwca 2020 r. i ponownie wprowadzone w październiku tego samego roku. Jednocześnie Ministerstwo Edukacji Narodowej (MEN) w swoim komunikacie z marca (https:// www.gov.pl/web/edukacja/zawieszenie-zajec-w-szkolach, 2020) zwróciło uwagę na stronę internetową www.epodreczniki.pl, tj. adres, pod którym znajduje się tzw. Zintegrowana Platforma Edukacyjna (ZPE), zawierająca bezpłatne e-materiały, zarówno do korzystania przez nauczycieli, jak i do samodzielnej nauki uczniów. Efekty tej zachęty pojawiły się szybko. Jak wynika z informacji MEN, w okresie od marca do czerwca 2020 r. liczba odsłon Zintegrowanej Platformy Edukacyjnej wynosiła średnio ok. $1 \mathrm{mln}$ dziennie. Łącznie, w okresie marzec - sierpień liczba odsłon wyniosła ponad $120 \mathrm{mln}$. W listopadzie 2020 r. konto na ZPE miało już ponad 6,3 mln użytkowników (https://epodreczniki.pl/a/ rozwijamy-zintegrowana-platforme-edukacyjna-epodrecznikipl/Dj4GZQNfw, 2020).

\section{GENEZA ZPE}

Zintegrowana Platforma Edukacyjna powstała w wyniku realizacji projektu systemowego „Tworzenie e-materiałów dydaktycznych do kształcenia ogólnego - etap II”, dofinansowanego ze środków Europejskiego Funduszu Społecznego (EFS), realizowanego przez Ośrodek Rozwoju Edukacji (ORE) w partnerstwie z Centrum Informatycznym Edukacji (CIE) od lipca 2018 r. do czerwca 2021 r. w ramach Programu Operacyjnego Wiedza Edukacja Rozwój (PO WER). ZPE została uruchomiona w styczniu 2019 r. pod adresem www.epodreczniki.pl, pod którym funkcjonowała wcześniej platforma utworzona w latach 2012-2015 podczas realizacji projektu „E-podręczniki” w ramach Programu Operacyjnego Kapitał Ludzki (PO KL). Projekt ten również realizowało ORE, a za platformę odpowiedzialny był jeden z partnerów - Poznańskie Centrum Superkomputerowo-Sieciowe (https://www.ore.edu.pl/2014/04/partnerzy/, 2020).

Oba wymienione wyżej projekty nie służyły jedynie powstaniu rozwiązania informatycznego, ale przede wszystkim miały na celu opracowanie i udostępnienie materiałów dydaktycznych. W ramach pierwszego projektu, zrealizowanego w latach 2012-2015, powstało 56 e-podręczników do 11 przedmiotów kształcenia ogólnego do nauczania na 
trzech etapach edukacyjnych (klasy 4-6 szkoły podstawowej, gimnazjum i szkoła ponadgimnazjalna) dla zakresu podstawowego, 12 e-podręczników do edukacji wczesnoszkolnej oraz 2661 zasobów metodycznych i dydaktycznych uzupełniających e-podręczniki.

Kolejne e-materiały zostały opracowane w ramach projektów realizowanych w latach 2016-2018. Wówczas przyjęty został taki system, w którym materiały powstają $\mathrm{w}$ ramach projektów konkursowych, natomiast za ich odbiór jakościowy odpowiadają eksperci z projektu systemowego w Ośrodku Rozwoju Edukacji. W ramach projektu systemowego „Tworzenie e-materiałów dydaktycznych do kształcenia ogólnego” odbierane więc były materiały, które tworzyli beneficjenci dwóch konkursów:

1. „Tworzenie e-materiałów dydaktycznych do kształcenia ogólnego służących rozwijaniu kompetencji kluczowych";

2. „Tworzenie e-materiałów dydaktycznych do kształcenia ogólnego służących rozwijaniu kompetencji kluczowych - abstrakty lekcji w języku angielskim".

W ramach pierwszego z nich powstało 100 audiobooków i 150 krótkich filmów edukacyjnych do 10 przedmiotów kształcenia ogólnego, 750 e-materiałów dydaktycznych do historii sztuki, historii muzyki, języka łacińskiego i kultury antycznej (zakres rozszerzony) oraz wiedzy o kulturze (zakres podstawowy), 310 e-materiałów do edukacji artystycznej: muzyki i plastyki dla szkoły podstawowej. Efektem drugiego konkursu było 2260 abstraktów lekcji w języku angielskim z e-podręczników przygotowanych wcześniej do nauki 10 przedmiotów kształcenia ogólnego.

$\mathrm{Z}$ kolei w projekcie, $\mathrm{w}$ ramach którego stworzono ZPE, odbierane są e-materiały edukacyjne tworzone przez beneficjentów konkursu „E-materiały dydaktyczne do 10 przedmiotów dla szkół kończących się egzaminem maturalnym”. Docelowo ma powstać 10125 e-materiałów dydaktycznych do 10 przedmiotów kształcenia ogólnego dla 4-letniego liceum i 5-letniego technikum (dla zakresu podstawowego i rozszerzonego) (Wniosek o dofinansowanie..., 2020).

\section{ZAWARTOŚĆ ZPE}

Wymienione wyżej materiały stanowią tylko część zawartości Zintegrowanej Platformy Edukacyjnej. Dla uczniów przeznaczone są cztery główne zbioryª materiały do kształcenia ogólnego, materiały wspierające kształcenie zawodowe, doradztwo edukacyjno-zawodowe, a także edukację za granicą. Jak wynika z informacji zamieszczonej na tej stronie przez MEN, na początku listopada $2020 \mathrm{r}$. znajdowało się na niej ponad 15 tys. materiałów, w tym ok. 8500 interaktywnych e-materiałów, ponad 3200 scenariuszy lekcji oraz 107 programów nauczania (https://epodreczniki.pl/a/rozwijamy-zintegrowanaplatforme-edukacyjna-epodrecznikipl/Dj4GZQNfw).

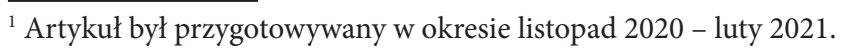


Wyniki wyszukiwania na ZPE wskazywały wówczas, że e-materiały do kształcenia ogólnego obejmują 4318 e-materiałów do szkoły podstawowej oraz 4238 do szkół ponadpodstawowych.

Zakładka „kształcenie zawodowe” zawierała wówczas łącznie 121 e-materiałów do języka obcego zawodowego dla 32 branż oraz 25 e-materiałów na temat podejmowania działalności gospodarczej. Pod hasłem „doradztwo zawodowe” znajdowały się informacje zawodoznawcze wraz z obudową dydaktyczną (plik tekstowy i 3 pliki multimedialne): 45 przeznaczonych dla uczniów edukacji wczesnoszkolnej, 78 dla uczniów klas 4-8 szkoły podstawowej oraz 78 dla młodzieży i dorosłych. Materiały te obejmowały łącznie 804 e-zasoby. Ostatni dział „edukacja za granicą” zawierał 18 materiałów wspierających nauczycieli w edukacji wczesnoszkolnej, 59 do języka polskiego oraz 25 dotyczących wiedzy o Polsce.

Wymienione wyżej materiały do języka obcego zawodowego powstały w latach 20172018 w ramach konkursu „Zwiększenie wykorzystania zmodernizowanych treści, narzędzi i zasobów wspierających proces kształcenia zawodowego (JOZ)", natomiast materiały dotyczące działalności gospodarczej - w ramach konkursu „Tworzenie materiałów multimedialnych (e-zasobów) z zakresu podejmowania i prowadzenia działalności gospodarczej (PDG)".

Informacje zawodoznawcze są efektem projektów realizowanych w ramach dwóch edycji konkursu „Przygotowanie i udostępnienie multimedialnych zasobów wspierających proces doradztwa dla wszystkich grup wiekowych (doradztwo)". W latach 2018-2019 powstało 115 informacji wraz z obudową dydaktyczną, na lata 2020-2021 zaplanowano stworzenie 141 kolejnych. Te materiały są odbierane przez ekspertów projektu systemowego ORE „Weryfikacja i odbiór produktów projektów konkursowych z Działania 2.14”.

Od momentu uruchomienia w styczniu 2019 r. Zintegrowana Platforma Edukacyjna jest nieustająco modyfikowana. Oprócz zbioru materiałów oferuje również inne funkcjonalności umożliwiające prowadzenie nauki zdalnej. Zawiera m.in. kreator ułatwiający tworzenie i udostępnianie materiałów, komunikator, dzięki któremu zalogowani użytkownicy mogą bezpośrednio porozumiewać się między sobą w czasie rzeczywistym, czy narzędzia umożliwiające tworzenie wideokonferencji. Wiele funkcjonalności zostało wprowadzonych w odpowiedzi na wynikające z pandemii potrzeby szkół.

\section{PLANY NA PRZYSZŁOŚĆ}

Do lipca 2020 r. ZPE była rozwijana ze środków budżetowych, a od sierpnia 2020 do końca 2021 r. będzie modyfikowana w ramach projektu unijnego „Rozwój funkcjonalności Zintegrowanej Platformy Edukacyjnej epodreczniki.pl zwiększających możliwości nauki zdalnej" realizowanego przez Centrum Informatyczne Edukacji. Zaplanowano również stworzenie kolejnych materiałów. Na luty 2021 r. założono rozpoczęcie realizacji projektu systemowego ORE „Tworzenie e-materiałów dydaktycznych do kształcenia ogólnego - etap III", w ramach którego będą odbierane materiały opracowywane przez beneficjentów dwóch konkursów, ogłoszonych w 2020 r.: 
1. „Tworzenie e-materiałów dydaktycznych do kształcenia ogólnego - III etap”,

2. „Tworzenie e-materiałów dydaktycznych do języków obcych”.

W ramach pierwszego konkursu utworzonych zostanie 1047 nowych e-materiałów do 16 przedmiotów kształcenia ogólnego oraz do edukacji wczesnoszkolnej. Ponadto, zaktualizowanych zostanie 3115 e-materiałów, które powstały w wyniku „rozszycia” e-podręczników. Efektem drugiego konkursu będzie 3474 e-materiałów do 6 języków obcych nowożytnych.

Jednocześnie w ramach systemowego projektu „Tworzenie e-zasobów do kształcenia zawodowego" (realizowanego w latach 2019-2022) eksperci ORE będą odbierali produkty opracowane w projektach realizowanych w ramach konkursu o tej samej nazwie, ogłoszonego w 2020 r. Powstanie 800 e-materiałów do kształcenia zawodowego dla 172 zawodów (198 kwalifikacji) w ramach 32 branż szkolnictwa branżowego.

\section{KONCEPCJE E-MATERIAŁÓW I STANDARDY JAKOŚCI}

Odbiór materiałów tworzonych w projektach konkursowych nie byłby możliwy bez określonych wymagań i kryteriów oceny. Podstawowymi dokumentami dla beneficjentów i ekspertów oceniających e-materiały, z którymi muszą być z zgodne tworzone materiały, są:

1. koncepcje: e-materiałów dydaktycznych do kształcenia ogólnego, e-materiałów dydaktycznych do nauki języków obcych nowożytnych oraz e-zasobów do kształcenia zawodowego;

2. standardy: merytoryczno-dydaktyczny, funkcjonalny, techniczno-graficzny i dostępności - dostosowane do każdego z konkursów;

3. wykazy tematów, których mają dotyczyć nowe materiały wraz z wyszczególnieniem multimediów, jakie mają zawierać.

Koncepcje zawierają teoretyczną podbudowę oraz praktyczne wskazówki, dotyczące tworzenia e materiałów. Koncepcja e-materiałów dydaktycznych do kształcenia ogólnego i koncepcja e-materiałów do języków obcych obejmuje strategie i metody sprzyjające aktywnemu uczeniu się, opis struktury e-materiałów dydaktycznych - odpowiednio do kształcenia ogólnego i do nauki języków obcych, a także rodzaje multimediów i ich rolę w nauczaniu. Ponadto pierwsza $\mathrm{z}$ tych koncepcji opisuje specyfikę obszarów nauczania w przypadku przedmiotów kształcenia ogólnego, a druga - założenia dotyczące nauczania języków obcych na poszczególnych etapach edukacyjnych. Z kolei koncepcja e-zasobów do kształcenia zawodowego zawiera założenia dotyczące nowoczesnego kształcenia zawodowego i efektywnej pracy z uczniem w szkolnictwie branżowym, opisuje specyfikę e-materiałów do kształcenia zawodowego oraz specyfikę materiałów multimedialnych w kształceniu zawodowym.

Standard merytoryczno-dydaktyczny służy do sprawdzania zgodności tworzonych e-materiałów z koncepcją w zakresie struktury, treści i wymagań merytorycznych dotyczących zasobów multimedialnych. W przypadku e-zasobów do kształcenia zawodowego standardy merytoryczno-dydaktyczne zostały opracowane dla poszczególnych kwalifikacji wyodrębnionych w zawodach szkolnictwa branżowego. Standard funkcjo- 
nalny odnosi się do wymaganych od zasobów multimedialnych funkcjonalności, czyli do ich funkcjonalnej charakterystyki zawartej w koncepcji. Standard techniczno-graficzny określa przede wszystkim techniczne wymagania dotyczące przygotowania plików źródłowych i umieszczania ich na platformie oraz wymagania edytorsko-graficzne. Za pomocą standardu dostępności weryfikuje się zgodność przygotowania e-materiałów z wytycznymi WCAG, zawierającymi zalecenia dotyczące tworzenia dostępnych serwisów internetowych.

Z wymienionymi wyżej dokumentami można zapoznać się na stronach internetowych:

- https://efs.men.gov.pl/nabory/tworzenie-e-materialow-dydaktycznych-doksztalcenia-ogolnego-iii-etap-eogolne/

- https://efs.men.gov.pl/nabory/ogloszenie-o-konkursie-powr-02-10-00ip-02-00-009-20-tworzenie-e-materialow-dydaktycznych-do-jezykow-obcych/

- https://efs.men.gov.pl/nabory/ogloszenie-o-konkursie-konkurs-nr-powr-02-15-00-ip-02-00-003-20-tworzenie-e-materialow-do-ksztalcenia-zawodowego/

\section{SPECJALNE POTRZEBY EDUKACYJNE}

Pojęcie „specjalne potrzeby edukacyjne” (SPE) funkcjonuje w literaturze przedmiotu od końca lat siedemdziesiątych. Po raz pierwszy oficjalnie użyto go w tzw. Warnock Report, opublikowanym w Wielkiej Brytanii w 1978 r. (Bogdanowicz, 1995; Krzyżyk, 2012; Olechowska, 2016; Zaremba, 2014). W raporcie tym wyróżniono trzy rodzaje specjalnych potrzeb edukacyjnych, wymagających wsparcia uczniów w zakresach: dydaktycznym, technicznym i psychospołecznym. Wsparcie dydaktyczne powinno opierać się na odpowiednio dobranym programie i metodach nauczania, techniczne - na dostosowaniu fizycznego otoczenia i zapewnieniu możliwości skorzystania $\mathrm{z}$ niezbędnych urządzeń i specjalnych środków dydaktycznych, a psychospołeczne - na stworzeniu właściwej atmosfery emocjonalnej.

W Polsce terminu „specjalne potrzeby edukacyjne” użyła w 1995 r. Marta Bogdanowicz w swoim artykule zatytułowanym „Uczeń o specjalnych potrzebach edukacyjnych”. Przytoczyła w nim propozycję z Warnock Report, zgodnie z którą SPE to potrzeby odnoszące się do tej grupy dzieci, które "nie potrafią podołać wymaganiom programu nauczania powszechnie obowiązującego w szkołach. Mają one większe trudności w uczeniu się niż większość dzieci w tym samym wieku, a trudności te przeszkadzają im w korzystaniu z powszechnie dostępnych form edukacji. (...) Są one w stanie kontynuować naukę, ale potrzebują pomocy pedagogicznej $\mathrm{w}$ formie specjalnego programu nauczania, specjalnych metod nauczania dostosowanych do ich potrzeb, ograniczeń i możliwości” (Bogdanowicz, 1995, s. 216). Oficjalnie ten termin pojawił się w dokumencie opracowanym przez Ministerstwo Edukacji Narodowej w 1998 r. „Reforma systemu kształcenia uczniów ze specjalnymi potrzebami edukacyjnymi". Zgodnie z tym dokumentem mianem SPE określa się „potrzeby, które w toku rozwoju dzieci i młodzieży wynikają z ich niepełnosprawności lub powstałe z innych przyczyn trudności w uczeniu się" (MEN, 1998, s. 11 za: Olechowska, 
2006, s. 121). Kolejne definicje opracował w 2008 r. Zespół Ekspertów ds. Specjalnych Potrzeb Edukacyjnych powołany przez Ministra Edukacji Narodowej. Zgodnie z nimi specjalne potrzeby rozwojowe i edukacyjne mają dzieci i młodzież u których stwierdzono: „spektrum objawów utrudniających lub uniemożliwiających funkcjonowanie: ruchowe, sensoryczne, poznawcze, w zakresie komunikacji, emocjonalno-społeczne i/lub psychiczne, wpływających na jakość życia i pełnienie ról społecznych teraz i/lub w przyszłości” oraz „zagrożenie niepełnosprawnością, wszelkie dysfunkcje, dysharmonie lub niesprawności mogące mieć negatywny wpływ na dalszy rozwój” (Zaremba, 2014, s. 15).

Jak zauważa Danuta Krzyżyk (2012), diagnozowanie specjalnych potrzeb edukacyjnych i podejmowanie odpowiednich działań często łączone jest z zagadnieniem trudności w uczeniu się. Biorąc pod uwagę Międzynarodową Klasyfikację Chorób i Problemów Zdrowotnych (ICD-10) oraz klasyfikację zaburzeń psychicznych opracowaną przez Amerykańskie Towarzystwo Psychiatryczne (DSM-IV), wyróżnia dwa kryteria, według których grupuje się uczniów ze specjalnymi potrzebami edukacyjnymi: kryterium psychiczne (psychologiczne) i kryterium organiczne. Pierwsza z tych kategorii obejmuje m.in. dzieci i młodzież z niepełnosprawnością intelektualną, z całościowymi zaburzeniami rozwojowymi, zaburzeniami rozwoju psychicznego, zachowania i emocji, ale także wybitnie uzdolnionych. Druga kategoria opiera się na specyficznych nieprawidłowościach $w$ funkcjonowaniu, wynikających m.in. $z$ dysfunkcji ruchowych, poznawczych, narządów mowy i zmysłów. Kryterium organiczne w dużej mierze pokrywa się z najczęściej spotykanymi przyczynami trudności w uczeniu się, do których Aleksandra Tomkiewicz-Bętkowska (2016) zalicza zaburzenia:

- rozwoju ruchowego (w tym: niezręczność ruchową, niezręczność manualną, zaburzenia w orientacji przestrzennej, zaburzenia w schemacie ciała, zaburzenia w funkcjonowaniu analizatorów: skórno-kinestetycznego i ruchowego, nieprawidłową lateralizację);

- spostrzeżeń wzrokowych;

- spostrzeżeń słuchowych;

- rozwoju mowy.

W przypadku uczniów ze specjalnymi potrzebami edukacyjnymi szczególne znaczenie ma indywidualizacja kształcenia, rozumiana jako strategia, która „z jednej strony uwzględnia możliwości i preferencje ludzi w zakresie sposobów uczenia się, z drugiej strony stwarza także warunki do kształtowania własnych hierarchii wartości, wyboru lub kreowania indywidualnych celów życiowych oraz realizacji tych celów, nieskrępowanego rozwoju osobowości, indywidualnego wyboru treści, metod i form kształcenia" (Lewowicki, 1993, s. 252). Zgodnie z tą definicją indywidualizacja kształcenia może przejawiać się w indywidualizacji celów edukacyjnych, różnicowaniu treści nauczania oraz odpowiednim doborze metod, form i środków kształcenia. Różnicowanie treści może dotyczyć przedmiotu nauczania i uczenia się a także zakresu i organizacji materiału (Lewowicki, 1993; Sajdak, 2008). Anna Sajdak do indywidualizacji procesu dydaktycznego zalicza także indywidualizację tempa nauczania, w szczególności tempa uczenia się wybranych treści, zgodnie z potrzebami i możliwościami konkretnych uczniów. 
Powyższy krótki przegląd definicji i terminów pokazuje, że pojęcie „specjalnych potrzeb edukacyjnych” obejmuje bardzo szeroki zakres zagadnień i dotyczy wielu rodzajów wsparcia. Korzystanie z technologii informacyjno-komunikacyjnych wymaga specyficznego podejścia do udostępniania informacji za pośrednictwem zasobów elektronicznych. Informacje te mogą być w formie tekstu, ilustracji, nagrania audio lub filmu. W dokumencie opublikowanym przez Europejską Agencję ds. Specjalnych Potrzeb i Edukacji Włączającej „dostępna informacja” oznacza informację, która podawana jest „w formatach umożliwiających każdemu użytkownikowi oraz każdej osobie uczącej się uzyskanie dostępu do treści 'na równych zasadach z innymi' (UNCRPD). Dostępna informacja to informacja, która:

- umożliwia wszystkim użytkownikom i osobom uczącym się łatwą orientację w treści oraz

- może być skutecznie odbierana i rozumiana przez różne kanały percepcyjne takie jak: wzrok i/lub słuch oraz/lub palce" (Turner-Cmuchal, 2015, s. 10).

Odpowiednie przygotowanie zasobów elektronicznych wymaga również uwzględnienia technologii wspomagających, czyli odpowiednio wyposażonego sprzętu komputerowego. Sposób interakcji z komputerem uzależniony jest od rodzaju zaburzenia, które determinuje konkretne problemy z odbiorem i rozumieniem informacji. Zasadniczo wyróżnia się cztery grupy użytkowników, których potrzeby muszą być uwzględniane przy tworzeniu dostępnych stron internetowych i zamieszczanych na nich materiałów: osoby z zaburzeniami wzroku, niesłyszące, osoby niesprawne ruchowo oraz osoby z niepełnosprawnością intelektualną i zaburzeniami poznawczymi (Paszkiewicz, Dębski, 2013). Każda z tych grup jest również wewnętrznie zróżnicowana i w zależności od konkretnych dysfunkcji wymaga innego wsparcia przy obsłudze komputera.

Uczniowie niewidomi korzystają z czytników ekranu zamieniających zapisany tekst w mowę, posługując się głównie klawiaturą. Jednak żeby czytnik w pełni przetworzył zawartość strony internetowej czy dokumentu elektronicznego, konieczne jest prawidłowe wykonanie serwisu i materiału (np. odpowiednia struktura i formatowanie, audiodeskrypcja do filmów i animacji, opisy alternatywne do ilustracji). Z kolei uczniowie słabowidzący posługują się programami powiększającymi obraz na ekranie, korzystają z możliwości zmiany kolorystyki i kontrastu. Niektórzy mają problem z rozpoznawaniem barw. Oznacza to, że nie można stosować koloru jako jedynej metody przekazywania informacji.

Dla uczniów niesłyszących niezbędne jest odpowiednie udostępnienie treści przekazywanej w formie dźwięku. Jednym wystarczą napisy (zapis ścieżki dźwiękowej), dla innych konieczne jest tłumaczenie na język migowy. Ważne jest także, by informacje były odpowiednio zredagowane i zrozumiałe.

Sposób interakcji z komputerem uczniów niesprawnych ruchowo zależy od konkretnej trudności, jaką ma dana osoba z obsługą klawiatury czy myszki komputerowej. Jedni korzystają z obu tych urządzeń, inni mogą posługiwać się wyłącznie klawiaturą lub urządzeniami wskazującymi działającymi podobnie do myszki. Istnieją także urządzenia i oprogramowanie umożliwiające poruszanie się po ekranie komputera za pomocą 
ruchów głowy, gałek ocznych, za pomocą ust lub komend głosowych. Strona internetowa powinna być tak zbudowana, by nie wykluczać żadnego z powyższych sposobów komunikowania się z komputerem.

Ostatnia z wymienionych grup, obejmująca uczniów z niepełnosprawnością intelektualną i zaburzeniami poznawczymi, jest najbardziej różnorodna, jednak wymaga przede wszystkim jednego podstawowego rozwiązania - intuicyjnej, prostej nawigacji i nieskomplikowanych treści. Dla części osób z tej grupy niezbędne może być opracowanie informacji w tzw. tekście łatwym do czytania.

Odrębnym przypadkiem są osoby chore na tzw. padaczkę fotogenną. Są one szczególnie wrażliwe na ruchome i migające elementy, takie jak animacje lub banery. Ze względu na możliwość wywołania ataku padaczki, należy unikać tego typu elementów na stronach internetowych.

\section{DEKLARACJA DOSTĘPNOŚCI ZPE}

Aktualny poziom dostępności Zintegrowanej Platformy Edukacyjnej określa „Deklaracja dostępności”, sporządzona na podstawie przeprowadzonej samooceny (https://platforma.epodreczniki.pl/declaration_of_accessibility).

Zgodnie $\mathrm{z}$ tą deklaracją podstawowe udogodnienia związane $\mathrm{z}$ dostępnością serwisu dla osób słabowidzących, niewidomych i niesłyszących zostały zapewnione. Jest zastosowany odpowiedni kontrast tekstu do tła, elementy interaktywne mają wyraźne obramowanie. W miarę możliwości informacje zamieszczane na platformie są pisane prostym językiem i z odpowiednim formatowaniem; informacje te są na bieżąco przeglądane i aktualizowane. Filmy i animacje posiadają napisy, a ilustracje są na bieżąco uzupełniane o teksty alternatywne. Po platformie można poruszać się za pomocą klawisza Tab, a do głównego obszaru można dotrzeć poprzez skip linki, czyli pomijając pewne sekcje na stronie. Linki przekierowujące użytkownika $w$ ramach serwisu otwierają się $w$ tym samym oknie, a prowadzące poza serwis - w nowym. Ponadto, jak wynika z deklaracji, odpowiednio zostały zbudowane i opisane formularze, a materiały, które znajdują się na platformie, można przeglądać za pomocą urządzeń mobilnych. Jak przyznali autorzy deklaracji: „Platforma w dużym stopniu spełnia wytyczne techniczne związane z dostępnością. Pomimo naszych starań może się jednak zdarzyć, że nie zawsze udało nam się to osiągnąć”.

Z komunikatów dostępnych dla zalogowanych użytkowników ZPE wynika, że w listopadzie 2020 r. przygotowano funkcję automatycznego tworzenia opisów alternatywnych dla wzorów matematycznych. Jeżeli dla wzoru nie uzupełniono opisu, zostanie tam umieszczony opis wygenerowany przez skrypt. Opisy generowane mogą być punktem startowym do ich dalszej rozbudowy, jeśli taka jest konieczna. Natomiast w grudniu 2020 r. wprowadzono zmiany w ćwiczeniach interaktywnych w celu zwiększenia ich dostępności. Użytkownicy uzyskali możliwość obsługi ćwiczeń z poziomu klawiatury i czytnika ekranowego. 


\section{STANDARD I KRYTERIA OCENY SPEŁNIENIA STANDARDU DOSTĘPNOŚCI WCAG}

Materiały, które zostaną opracowane w latach 2021-2023, będą musiały spełniać wymagania dokumentu „Standard i kryteria oceny spełnienia standardu dostępności WCAG e-materiałów dydaktycznych (...)" odpowiednio: do kształcenia ogólnego lub do nauki języków obcych nowożytnych lub do kształcenia zawodowego. Wymagania i kryteria oceny spełnienia standardu dostępności są oczywiście dla wszystkich tworzonych materiałów jednakowe. Zaktualizowane i dostosowane do aktualnego stanu prawnego, w tym do WCAG 2.1 na poziomie AA, zostaną także e-materiały, które powstały z „rozszytych” e-podręczników stworzonych w ramach PO KL i które również będą musiały być zgodne $\mathrm{z}$ tym standardem.

Podstawą prawną standardu jest Ustawa z dnia 4 kwietnia 2019 r. o dostępności cyfrowej stron internetowych i aplikacji mobilnych podmiotów publicznych (Dz. U. 2019, poz. 848), zgodnie z którą (art. 5 ust. 1) podmioty publiczne są zobowiązane do zapewnienia dostępności cyfrowej „przez spełnienie przez ich stronę internetową lub aplikację mobilną wymagań określonych w załączniku do ustawy”. Drugim dokumentem, do którego odwołuje się standard dostępności, jest opracowanie „Web Content Accessibility Guidelines (WCAG) 2.1" (W3C 2018).

Załącznik do powyższej ustawy, czyli „Wytyczne dla dostępności treści internetowych 2.1 stosowane dla stron internetowych i aplikacji mobilnych w zakresie dostępności dla osób niepełnosprawnych" zawierają 13 wytycznych pogrupowanych wg 4 zasad i wyszczególniają 49 kryteriów sukcesu na poziomie A (minimalnym) i AA (zalecanym) - spośród 50 określonych w standardzie WCAG 2.1. Ustawa nie uwzględnia również 28 kryteriów na poziomie AAA (komfortowym). Poziom minimalny zapobiega temu, by pewne grupy osób całkowicie nie miały dostępu do informacji na stronie, poziom zalecany zapobiega utrudnionemu dostępowi, natomiast poziom komfortowy odnosi się do kryteriów, które warto spełnić, by dostęp do strony nie był w żaden sposób utrudniony.

Cztery zasady, zgodnie z którymi powinna być zbudowana strona internetowa i aplikacja mobilna, to: funkcjonalność, kompatybilność, postrzegalność i zrozumiałość.

W art. 4 wymienionej ustawy funkcjonalność zdefiniowano jako właściwość strony internetowej lub aplikacji mobilnej, która umożliwia użytkownikowi korzystanie ze wszystkich funkcji oferowanych przez daną stronę lub aplikację - w standardzie ORE oznacza to „dostępność każdego elementu przy użyciu klawiatury; zapewnienie wystarczającego czasu na wykonanie danej czynności; możliwość zatrzymania, pauzowania akcji; zapewnienie odpowiedniej nawigacji po treści - logicznej i intuicyjnej; określony cel każdego linku; stosowanie nagłówków i etykiet”. Oznacza to również, że nie należy stosować świetlnych błysków ani migających elementów.

Kompatybilność to według ustawy właściwość umożliwiająca „stronie lub aplikacji współpracę z możliwie największą liczbą programów, w tym z narzędziami i programami wspomagającymi osoby niepełnosprawne" - według standardu ORE należy zapewnić, by treść materiałów była poprawnie interpretowana przez technologie asystujące. 
W ustawie postrzegalność oznacza właściwość, dzięki której użytkownik może odbierać daną stronę lub aplikację mobilną za pomocą zmysłu słuchu, wzroku lub doty$\mathrm{ku}$ - standard ORE wymaga w związku z tym, by każda informacja nietekstowa miała tekst alternatywny, a media zależne od czasu - alternatywy, powinny być zapewnione różnorodne formy prezentacji treści bez utraty informacji i struktury oraz wartości edukacyjnej oraz kontrola dźwięków. Nie można stosować „kolorów jako jedynej metody przekazywania treści i rozróżniania elementów wizualnych".

Zrozumiałość zdefiniowano w ustawie jako właściwość umożliwiającą „zrozumienie treści i sposobu ich prezentacji” - w standardzie ORE oznacza to, że treści e-materiałów i obsługa elementów muszą być czytelne oraz dostosowane do wieku uczniów i ich możliwości, opisy alternatywne powinny zawierać informacje, które są ważne ze względu na treść materiału, czyli mieć „wartość edukacyjną umożliwiającą osiąganie założonych przez autora celów". Ponadto instrukcje opisujące sposób korzystania z e-materiału i jego poszczególnych części powinny być szczegółowe i przedstawiać kolejne etapy korzystania $\mathrm{z}$ niego.

Tabela „Kryteria oceny spełnienia standardu dostępności WCAG e-materiałów do kształcenia ogólnego" zawiera 49 kryteriów wymaganych przez Ustawę o dostępności cyfrowej stron internetowych i aplikacji mobilnych podmiotów publicznych (Dz. U. 2019, poz. 848). Do każdego kryterium przyporządkowano od jednego do kilkunastu testów weryfikujących, które są sprawdzane i odnotowywane - czy wymaganie jest spełnione, czy nie, ewentualnie że nie dotyczy danego materiału. Testów jest łącznie 103, z czego 38 (37\%) nie podlega ocenie, ponieważ dane wymaganie jest związane $\mathrm{z}$ funkcjonalnością platformy i nie zależy od twórcy materiału. E-materiał może być uznany za dostępny i zaakceptowany tylko w sytuacji, kiedy wszystkie wymagania są spełnione.

Dostępność musi być zapewniona w odniesieniu do wszystkich elementów e-materiałów i wszystkich rodzajów multimediów, które w nich występują. Najważniejsze dla uczniów ze specjalnymi potrzebami jest to, aby każdy multimedialny element miał nadaną jednoznaczną nazwę, która wyjaśnia, czego dotyczy lub co prezentuje dany element. W szczególności multimedium, $\mathrm{z}$ którego uczeń z niepełnosprawnością nie może w pełni skorzystać - np. gra edukacyjna o charakterze rzeczywistości rozszerzonej (AR - ang. augmented reality), powinno posiadać opis alternatywny lub być zastąpione innym, dostępnym multimedium.

Ważną okolicznością, która ma zapewnić dostępność materiałów, jest fakt, że beneficjenci konkursowi, którzy będą opracowywali e-materiały, zobowiązani są do powołania w projekcie zespołu opracowującego e-materiały, obejmującego m.in. specjalistów w zakresie WCAG oraz tworzenia e-materiałów w sposób uniwersalny, uwzględniający potrzeby uczniów z różnymi rodzajami niepełnosprawności. Na etapie składania wniosków o dofinansowanie w przypadku materiałów do kształcenia ogólnego i języków obcych dodatkowo punktowana była deklaracja zaangażowania pedagogów specjalnych, tj. tyflopedagoga lub surdopedagoga lub oligofrenopedagoga. Po stronie ORE zaangażowani będą eksperci, oceniający dostosowanie e-materiałów i spełnianie standardu. 


\section{STANDARDY DOSTĘPNOŚCI E-MATERIAŁÓW DO KSZTAŁCENIA ZAWODOWEGO DLA UCZNIÓW ZE SPE}

Beneficjentów projektu „Tworzenie e-zasobów do kształcenia zawodowego” obowiązują dodatkowo cztery dokumenty:

1. „Koncepcja i założenia standardów dostępności e-materiałów do kształcenia zawodowego dla uczniów ze SPE. Uczniowie niewidomi i słabowidzący”.

2. „Standard dostępności dla osób niewidomych i słabowidzących dla e-zasobów”.

3. „Koncepcja i założenia standardów dostępności e-materiałów do kształcenia zawodowego dla uczniów ze SPE. Uczniowie z niepełnosprawnością intelektualną w stopniu lekkim".

4. „Standard dostępności dla osób z niepełnosprawnością intelektualną w stopniu lekkim e-zasobów dla kwalifikacji wyodrębnionych w zawodach".

Szczególne uwzględnienie dostępności e-materiałów dla tych dwóch grup uczniów wynika z faktu, że w ramach klasyfikacji zawodów szkolnictwa branżowego wyodrębniono branże i zawody dedykowane wyłącznie uczniom niewidomym i słabowidzącym oraz dedykowane wyłącznie uczniom z niepełnosprawnością intelektualną w stopniu lekkim.

Wśród zawodów dedykowanych pierwszej z tych grup znajdują się trzy: technik prac biurowych w branży ekonomiczno-administracyjnej, technik masażysta w opiece zdrowotnej i technik tyfloinformatyk w branży teleinformatycznej.

Natomiast uczniowie z niepełnosprawnością intelektualną w stopniu lekkim mogą wybierać spośród siedmiu zawodów, jako pracownicy pomocniczy: stolarza (branża drzewno-meblarska), fryzjera (branża fryzjersko-kosmetyczna), gastronomii i obsługi hotelowej (branża hotelarsko-gastronomiczno-turystyczna), mechanika i ślusarza (branża mechaniczna) oraz krawca (branża przemysłu mody).

Koncepcje i założenia standardów dostępności dla uczniów ze specjalnymi potrzebami edukacyjnymi zawierają opis podstawowych wyznaczników indywidualizacji procesu dydaktycznego dla każdej z wymienionych wyżej grup uczniów, psychopedagogiczną charakterystykę uczniów z niepełnosprawnością wzroku i uczniów z niepełnosprawnością intelektualną w stopniu lekkim, a także opis specyficznych wymagań, dotyczących dostępności e-materiałów, w szczególności w zawodach dedykowanych odpowiednio pierwszej i drugiej grupie uczniów.

Z kolei same standardy dostępności zawierają szczegółowe wymagania/kryteria weryfikacji dla e-zasobów (w tym dla poszczególnych multimediów) i służą do sprawdzenia, czy dany materiał spełnia dane wymaganie całkowicie, częściowo, czy nie spełnia go w ogóle.

\section{METODOLOGIA PODJĘTYCH ANALIZ}

Celem analiz było udzielenie odpowiedzi na pytanie, w jaki sposób można zapewnić dostępność nauki zdalnej dla uczniów, którzy wymagają specyficznego wsparcia w zakresie korzystania z technologii informacyjno-komunikacyjnych. Skupienie na konkretnym rozwiązaniu zastosowanym w Ośrodku Rozwoju Edukacji zaważyło na opracowaniu 
swoistego autotelicznego studium przypadku (por. Stake, 2009). Możliwości organizacyjne wpłynęły na ograniczenie metod zbierania danych i źródeł informacji. Dane do analizy zostały zebrane ze stron Ministerstwa Edukacji Narodowej (od 1.01.2021 r. Ministerstwa Edukacji i Nauki) i skonfrontowane z wiedzą teoretyczną na podstawie literatury przedmiotu. Z pewnością warto by było uzupełnić dane o opinie użytkowników Zintegrowanej Platformy Edukacyjnej, w szczególności uczniów ze specjalnymi potrzebami edukacyjnymi oraz ich nauczycieli i rodziców.

Opisany przypadek nie może stanowić podstawy do sformułowania bardziej ogólnych wniosków czy poszerzenia wiedzy o większej grupie zjawisk, ale można go potraktować jako przykład tzw. dobrej praktyki. Jest to koncepcja, która powstała w ramach nauki o zarządzaniu i „określa działanie, które przyniosło konkretne, pozytywne rezultaty, zawiera $\mathrm{w}$ sobie pewien pierwiastek innowacyjności, jest trwałe i powtarzalne, możliwe do zastosowania w podobnych warunkach w innym miejscu lub przez inne podmioty" (Brajer-Marczak, 2017, s. 17).

\section{PODSUMOWANIE}

Pandemia koronawirusa wymusiła zwiększenie zainteresowania wśród nauczycieli i uczniów materiałami dydaktycznymi oferowanymi w formie elektronicznej, w szczególności zamieszczonymi na Zintegrowanej Platformie Edukacyjnej pod adresem https:// epodreczniki.pl/. W tej grupie odbiorców znaleźli się m.in. uczniowie ze specjalnymi potrzebami edukacyjnymi. Sama ZPE, jak i e-materiały, które są na niej zamieszczone, w dużej mierze spełniają wymagania dostępności cyfrowej stron internetowych i mogą być wykorzystywane zarówno w trakcie nauczania zdalnego, jak i samodzielnej pracy uczniów.

Przedstawione rozwiązanie, przyjęte w celu zapewnienia dostosowania e-materiałów dydaktycznych znajdujących się na tej stronie do standardu WCAG oraz wymagań uczniów ze SPE, stanowi przykład dobrej praktyki, która może być inspiracją dla twórców innych serwisów internetowych oraz elektronicznych opracowań dostępnych dla wszystkich.

Podkreślić należy, że Zintegrowana Platforma Edukacyjna, spełniająca standardy dostępności dla uczniów ze specjalnymi potrzebami edukacyjnymi, bezspornie wpisuje się $\mathrm{w}$ ideę indywidualizacji procesu dydaktycznego oraz wyrównywania szans edukacyjnych. Jest to efekt funkcjonalności, umożliwiającej nauczycielom konstruowanie e-materiałów odpowiednio do potrzeb i możliwości poszczególnych uczniów, stosownie do ich zainteresowań i predyspozycji. Nauczyciele mogą decydować zarówno o treści, jak i o organizacji materiału nauczania - strukturze, chronologii, funkcjonalności czy układzie przyczynowo-skutkowym. W ten sposób idea e-materiałów odpowiada zarówno na potrzeby uczniów z trudnościami w uczeniu się, jak i tych szczególnie uzdolnionych. 


\section{BIBLIOGRAFIA}

Bogdanowicz, M. (1995). Uczeń o specjalnych potrzebach edukacyjnych. Psychologia Wychowawcza, 3, 216-222.

Brajer-Marczak, R. (2017). Dobre praktyki w doskonaleniu procesów biznesowych. Studia Informatica Pomerania, 43 (1), 15-25.

Koncepcja i założenia standardów dostępności e-materiałów do kształcenia zawodowego dla uczniów ze SPE. Uczniowie niewidomi i słabowidzący (2020). https://efs.men.gov.pl/ nabory/ogloszenie-o-konkursie-konkurs-nr-powr-02-15-00-ip-02-00-003-20-tworzenie-e-materialow-do-ksztalcenia-zawodowego/

Koncepcja i założenia standardów dostępności e-materiałów do kształcenia zawodowego dla uczniów ze SPE. Uczniowie z niepełnosprawnością intelektualną w stopniu lekkim (2020). https://efs.men.gov.pl/nabory/ogloszenie-o-konkursie-konkurs-nr-powr-02-15-00-ip-02-00-003-20-tworzenie-e-materialow-do-ksztalcenia-zawodowego/

Krzyżyk, D. (2012). Specjalne potrzeby edukacyjne dzieci i młodzieży - zarys problematyki. W: A. Guzy, D. Krzyżyk (red.), Praca z uczniem o specjalnych potrzebach edukacyjnych. T. 1 (7-16).Wydawnictwo Pedagogiczne ZNP.

Lewowicki, T. (1993). Indywidualizacja w kształceniu. W: W. Pomykało (red.), Encyklopedia pedagogiczna (251-256). Fundacja Innowacja.

MEN (1998). Reforma systemu kształcenia uczniów ze specjalnymi potrzebami edukacyjnymi. Ministerstwo Edukacji Narodowej.

Olechowska, A. (2006). Edukacja dzieci o specjalnych potrzebach. Część 8. W: Małe dziecko $w$ Polsce. Raport o sytuacji edukacji elementarnej (120-135). Fundacja Rozwoju Dzieci.

Olechowska, A. (2016). Specjalne potrzeby edukacyjne. Wydawnictwo Naukowe PWN.

Paszkiewicz, D., Dębski, J. (2013). Dostępność serwisów internetowych. Dobre praktyki w projektowaniu serwisów internetowych dostępnych dla osób z różnymi rodzajami niepełnosprawności. Stowarzyszenie Przyjaciół Integracji.

Sajdak, A. (2008). Edukacja kreatywna. Wydawnictwo WAM.

Stake, R.E. (2009). Jakościowe studium przypadku. W: N.K. Denzin, Y.S. Lincoln (red.), Metody badań jakościowych. Tom 1 (623-654). Wydawnictwo Naukowe PWN.

Standard dostępności dla osób niewidomych i słabowidzących dla e-zasobów (2020). https:// efs.men.gov.pl/nabory/ogloszenie-o-konkursie-konkurs-nr-powr-02-15-00-ip-02-00-003-20-tworzenie-e-materialow-do-ksztalcenia-zawodowego/

Standard dostępności dla osób z niepełnosprawnością intelektualną w stopniu lekkim e-zasobów dla kwalifikacji wyodrębnionych w zawodach (2020). https://efs.men.gov.pl/ nabory/ogloszenie-o-konkursie-konkurs-nr-powr-02-15-00-ip-02-00-003-20-tworzenie-e-materialow-do-ksztalcenia-zawodowego/

Standard i kryteria oceny spełnienia standardu dostępności WCAG e materiałów dydaktycznych do kształcenia ogólnego (2020). https://efs.men.gov.pl/nabory/tworzenie-ematerialow-dydaktycznych-do-ksztalcenia-ogolnego-iii-etap-eogolne/ 
Standard i kryteria oceny spełnienia standardu dostępności WCAG e-materiałów dydaktycznych do nauki języków obcych nowożytnych (2020). https://efs.men.gov.pl/nabory/ ogloszenie-o-konkursie-powr-02-10-00-ip-02-00-009-20-tworzenie-e-materialow-dydaktycznych-do-jezykow-obcych/

Tomkiewicz-Bętkowska, A. (2016). ABC pedagoga specjalnego. Razem łatwiej. Nowe doświadczenia. Oficyna Wydawnicza Impuls.

Turner-Cmuchal, M. (red.) (2015). Wytyczne dla dostępności informacji. Technologie informacyjno-komunikacyjne (TIK) w zapewnianiu dostępności informacji w procesie uczenia się (ICT4IAL). Europejska Agencja ds. Specjalnych Potrzeb i Edukacji Włączającej.

W3C (2018). Web Content Accessibility Guidelines (WCAG) 2.1. https://www.w3.org/TR/ WCAG21/

Wniosek o dofinansowanie projektu pozakonkursowego o charakterze koncepcyjnym „Tworzenie e-materiałów dydaktycznych do kształcenia ogólnego - etap II” (2020), komputeropis.

Zaremba, L. (2014). Specjalne potrzeby rozwojowe i edukacyjne dzieci i młodzieży. Identyfikowanie SPR i SPE oraz sposoby ich zaspokajania. Ośrodek Rozwoju Edukacji.

\section{AKTY PRAWNE}

Ustawa z dnia 4 kwietnia 2019 roku o dostępności cyfrowej stron internetowych i aplikacji mobilnych podmiotów publicznych. Dz.U. 2019 poz. 848. 